\title{
PENGARUH PENGGUNAAN MODEL PEMBELAJARAN POE2WE BERBANTUAN MEDIA VIDEO POWTOON PADA MATERI DINAMIKA ROTASI
}

\author{
Ilham Mubarok ${ }^{1}, \mathrm{Nana}^{2}$ \\ ${ }^{1}$ Mahasiswa Program Studi Pendidikan Fisika, Universitas Siliwangi \\ ${ }^{2}$ Dosen Program Studi Pendidikan Fisika, Universtias Siliwangi \\ Universitas Siliwangi Tasikmalaya \\ *Email: ilhammubarok05@gmail.com
}

\begin{abstract}
In this study the problem found in the field is that educators are less utilizing the media for the learning process so that students feel bored and lack understanding of learning materials that are only assisted by printed textbooks and lecture methods used by educators in learning activities carried out in class so that students. To realize an interesting learning learning videos need to be developed, one of the interesting learning videos is to use the video assisted Powtoon application. The method used in this article is literature study. Data from the literature is collected and analyzed to be presented in the results and discussion to draw conclusions. The results of the discussion showed that the POE $\mathrm{E}_{2} \mathrm{WE}$ model assisted by Powtoon video media can be applied in rotational dynamics learning and provides a positive response to the attractiveness of Learning Videos so that students can maximize the understanding of the material.
\end{abstract}

Keywords: $\mathrm{POE}_{2}$ WE, Powtoon, Rotational dynamics, Learning videos

Abstrak: Pada penelitian ini masalah yang ditemukan dilapangan yaitu pendidik kurang memaksimalkan penggunaan media untuk proses pembelajaran sehingga pesertaa didik merasa bosan dan kurang memahami materi pembelajaran yang hanya berbantu media buku cetak serta metode ceramah yang digunakan oleh pendidik pada kegiatan pembelajaran yang dilakukan dikelas sehingga peserta didik merasa bosan. Untuk mewujudkan pembelajaran yang menarik perlu dikembangkannya video pembelajaran, salah satu video pembelajaran yang menarik adalah menggunakan Video berbantu aplikasi Powtoon. Metode yang digunakan dalam artikel ini adalah studi pustaka. Data dari literature dikumpulkan dan dianalisis untuk disajikan dalam hasil dan diskusi untuk menarik kesimpulan. Hasil penulisan menunjukan bahwa model $\mathrm{POE}_{2} \mathrm{WE}$ berbantuan media video Powtoon dapat diterapkan dalam pembelajaran dinamika rotasi dan memberikan respon positif terhadap kemenarikan Video Pembelajaran sehingga siswa dapat memaksimalkan pemahaman materi.

Kata kunci: $\mathrm{POE}_{2}$ WE, Powtoon, Dinamika rotasi, Video pembelajaran

\section{PENDAHULUAN}

Dalam proses belajar mengajar, hal utama yang diinginkan adalah keberhasilan siswa dalam memahami materi pembelajaran yang diajarkan serta mencapai tujuan-tujuan pembelajaran selama proses belajar mengajar di sekolah. Untuk mencapai keberhasilan tersebut, guru harus membimbing siswa selama dalam proses belajar mengajar agar siswa dapat mengembangkan pengetahuannya sesuai dengan bidang pengetahuan yang dipelajarinya. Disamping itu, guru juga harus menguasai materi pembelajaran, mampu membuat materi pembelajaran yang disampaikan menarik minat dan perhatian sehingga siswa menjadi lebih aktif selama proses belajar mengajar. Dengan adanya hal tersebut, 
peran guru dalam proses belajar mengajar tidak hanya sekedar menyampaikan materi saja, melainkan dapat juga memanfaatkan keberadaan teknologi menjadi alat bantu dalam membuat pembelajaran menjadi lebih menarik.

Menurut Bernard Renaldy Suteja dkk (2008: 241), "Teknologi informasi memungkinkan penciptaan teknik pengajaran baru, yaitu melalui media interaktif cd ataupun video". Oleh karena itu, guru tidak hanya selalu bisa berpatokan pada media papan tulis dan metode ceramah saja selama proses belajar mengajar jika ingin mencapai tujuan pembelajaran yang baik, melainkan juga harus ditambah dengan bantuan media yang bisa membuat penyampaian materi pembelajaran menjadi lebih menarik dalam proses belajarmengajar sehingga siswa akan lebih terangsang dalam mengikuti proses belajar mengajar tersebut.

Salah satu media yang dapat digunakan dalam proses belajar mengajar adalah media pembelajaran audiovisual. Media ini merupakan media yang tidak hanya didengar melainkan juga bisa dilihat secara bersamaan. Media audiovisual adalah media yang mempunyai unsur suara dan unsur gambar (Syaiful Bahri Djamarah dan Aswan Zain, 2013: 124). Ada beberapa media pembelajaran audiovisual yang dapat digunakan dalam kegiatan pembelajaran salah satunya adalah powtoon.

PowToon adalah web apps berbasis IT yang bisa digunakan untuk membuat presentasi atau video animasi kartun dengan mudah. Menurut Shannon Mershand (2014), "PowToon is Web-based animation software that allows you to quickly and easily create animated presentations with your students by manipulating pre-created objects, imported images, provided music and user created voice-overs". Dari pengertian tersebut dapat diartikan powtoon merupakan animasi perangkat lunak berbasis layanan online yang memungkinkan pengguna dengan cepat dan mudah membuat presentasi animasi dengan memanipulasi objek, memasukkan gambar, memasukkan musik dan dapat juga memasukkan rekaman suara penggunanya. Lebih lanjut Shannon Mershand (2014) juga menyatakan“ Powtoon can be used by educators to create animated presentations of content for students to view".

Pemilihan media pembelajaran audiovisual powtoon sebagai media pembelajaran sangat tepat apabila digunakan untuk membangkitkan motivasi belajar siswa dalam proses pembelajaran. Karena, video animasi powtoon ini mempunyai beragam animasi fitur animasi sangat menarik diantaranya animasi tulisan tangan, animasi kartun, dan efek transisi yang lebih hidup serta pengaturan time line yang sangat mudah. Selain itu juga media powtoon ini mudah dijadikan media penyampaian materi pembelajaran dengan cara yang menarik, sehingga siswa tidak jenuh dengan materi yang guru sampaikan.

Dengan penggabungan model dan media pembelajaran diharapkan peserta didik akan lebih antusias dalam belajar dan lebih memahami materi yang telah dipelajarinya dari pada sebelumnya. Berdasarkan uraian di atas maka diadakan penelitian yang berjudul "Pengaruh Penggunaan Model Pembelajaran $\mathrm{POE}_{2} \mathrm{WE}$ Berbantuan Media Video Powtoon Pada Materi Dinamika Rotasi”.

\section{METODE PENELITIAN}

Metode yang digunakan dalam artikel ini adalah studi literature atau studi pustaka. Data dikumpulkan dan dianalisis disajikan dalam hasil dan pembahasan untuk menarik kesimpulan. Penelitian selanjutnya dikembangkan untuk menjadi Blended Learning model dengan mengusung inovasi pembelajaran model $\mathrm{POE}_{2} \mathrm{WE}$ berbasis digital. 


\section{HASIL PENELITIAN DAN PEMBAHASAN}

\section{A. Model POE 2 WE}

Model $\mathrm{POE}_{2} \mathrm{WE}$ Model pembelajaran Prediction, Observation, Explanation, Elaboration, Write dan Evaluation $\left(\mathrm{POE}_{2} \mathrm{WE}\right)$ dikembangkan dari model pembelajaran POEW dan model pembelajaran Fisika dengan Pendekatan Konstruktivistik. Pengembangan ini dilakukan untuk sebagai penyempurnaan kedua model sebelumnya. Model $\mathrm{POE}_{2} \mathrm{WE}$ merupakan model pembelajaran yang dikembangkan untuk mengetahui pemahaman peserta didik mengenai suatu konsep dengan pendekatan konstruktivistik. Model ini membangun pengetahuan dengan urutan proses yaitu meramalkan atau memprediksi solusi dari permasalahan, melakukan eksperimen untuk membuktikan prediksi, kemudian menjelaskan hasil eksperimen yang diperoleh secara lisan maupun tertulis, membuat contoh penerapan dalam kehidupan seharihari, menuliskan hasil diskusi dan memuat evaluasi tentang pemahaman peserta didik baik secara lisan maupun tertulis (Nana et al., 2014).

Model pembelajaran $\mathrm{POE}_{2} \mathrm{WE}$ dapat menjadikan peserta didik sebagai subjek di dalam pembelajaran. peserta didik secara aktif menemukan suatu konsep melalui pengamatan atau eksperimen secara langsung, bukan dari menghafal buku materi maupun penjelasan dari guru. Model ini memungkinkan peserta didik aktif dalam proses pembelajaran, memberikan kesempatan kepada peserta didik untuk mengkonstrukssi pengetahuannya, mengkomunikasikan pemikirannya dan menuliskan hasil diskusinya sehingga peserta didik lebih menguasai dan memahami konsep yang akan berdampak pada peningkatan prestasi belajar peserta didik Model ini memberikan kesempatan kepada peserta didik untuk melakukan konstruksi pengetahuan yang dimilikinya, melakukan pengamatan terhadap fenomena serta mengkomunikasikan gagasan yang dia perolah dari proses diskusi sehingga peserta didik akan lebih mudah menguasai konsep yang diajarkan (Nana, 2014, 2016; Nana et al., 2014; Permatasari, 2011; Rahayu et al., 2013; Samosir, 2010).

Penggabungan tahapan-tahapan pembelajaran model POEW dan model pembelajaran Fisika dengan Pendekatan Konstruktivistik maka dapat di susun langkah-langkah pembelajaran model $\mathrm{POE}_{2} \mathrm{WE}$ secara terinci sebagai berikut:

a) Prediction

Tahap prediction yaitu peserta didik membuat prediksi atau dugaan awal terhadap suatu permasalahan. Permasalahan yang ditemukan berasal dari pertanyaan dan gambar tentang materi yang disampaikan oleh guru yang ada di Lembar Kerja peserta didik (LKS)/buku peserta didik sebelum peserta didik membuat prediksi. Pembuatan prediksi jawaban tahap Prediction pada model POEW identik dengan fase Engagenent pada pendekatan konstruktivistik. Guru mengajukan pertanyaan yang dapat mendorong peserta didik untuk dapat membuat prediksi atau jawaban sementara dari suatu permasalahan

b) Observation

Tahap Observation yaitu untuk membuktikan prediksi yang telah di buat oleh pesera didik. Peserta didik diajak melakukan eksperimen berkaitan dengan masalah atau persoalan yang di temukan. Selanjutnya peserta didik mengamati apa yang terjadi, kemudian peserta didik menguji kebenaran dari dugaan 
sementara yang telah dibuat. Tahap Observation pada model POEW identik dengan fase Exploration pada pendekatan konstruktivistik.

c) Explanation

Tahap Explanation atau menjelaskan yaitu peserta didik memberikan penjelasan terhadap hasil eksperimen yang telah dilakukan. Penjelasan dari peserta didik dilakukan melalui diskusi dengan anggota kelompok kemudian tiap kelompok mempresentasikan hasil diskusinya di depan kelas. Jika prediksi yang di buat peserta didik ternyata terjadi di dalam eksperimen, maka guru membimbing peserta didik merangkum dan memberi penjelasan untuk menguatkan hasil eksperimen yang dilakukan. Namun jika prediksi peserta didik tidak terjadi dalam eksperimen, maka guru membantu peserta didik mencari penjelasan mengapa prediksi atau dugaannya tidak benar. Tahap explanation identik dengan fase explanation pada pendekatan konstuktivistik.

d) Elaboration

Tahap elaboration yaitu peserta didik membuat contoh atau menerapkan konsep dalam kehidupan sehari-hari. Tahap elaboration di ambil dari pendekatan konstruktivistik. Tahap ini guru medorong peserta didik untuk menerapkan konsep baru dalam situasi baru sehingga peserta didik lebih memahami konsep yang di ajarkan guru. Tahap ini pengembangan dari pendekatan konstruktivistik.

e) Write

Tahap write atau menulis yaitu melakukan komunikasi secara tertulis,merefleksikan pengetahuan dan gagasan yang dimiliki peserta didik Menurut Masingilia dan Wisniowska (1996) dalam (Yamin \& Ansari, 2012) menulis dapat membantu peserta didik untuk mengekspresikan pengetahuan dan gagasan mereka. peserta didik menuliskan hasil diskusi dan menjawab pertanyaan yang ada pada LKS. Selain itu pada tahap write ini, peserta didik membuat kesimpulan dan laporan dari hasil eksperimen. Tahap ini merupakan pengembangan dari model TTW.

f) Evaluation

Tahap Evaluation yaitu evaluasi terhadap pengetahuan, keterampilan dan perubahan proses berfikir peserta didik. Pada tahap ini peserta didik di evaluasi tentang materi gerak lurus berupa lisan maupun tulisan. Tahap ini merupakan pengembangan dari pendekatan konstruktivistik.

Penggabungan tahap-tahap model POEW dan pendekatan konstruktivistik dapat di lihat pada Tabel 1 dan 2.

Tabel 1. Sintaks Pengembangan model POE2WE

\begin{tabular}{|c|l|c|c|}
\hline No. & $\begin{array}{c}\text { Sintaks POEW } \\
\text { (Samosir, 2010) }\end{array}$ & $\begin{array}{c}\text { Sintaks model } \\
\text { Pembelajaran dengan } \\
\text { Pendekatan } \\
\text { Konstruktivistik } \\
\text { (Duffy \& Jonassen, } \\
\text { 1992) }\end{array}$ & $\begin{array}{c}\text { Model POE2WE (Nana et } \\
\text { al., 2014) }\end{array}$ \\
\hline 1. & $\begin{array}{l}\text { (Prediction) } \\
\text { membuat } \\
\text { prediksi, }\end{array}$ & $\begin{array}{l}\text { (Engagement) } \\
\text { pendahuluan membuat } \\
\text { pertanyaan menggali }\end{array}$ & $\begin{array}{l}\text { (Prediction) Membuat dugaan } \\
\text { atau prediksi. Tahap }\end{array}$ \\
\hline
\end{tabular}




\begin{tabular}{|c|c|c|c|}
\hline & $\begin{array}{l}\text { membuat } \\
\text { dugaan }\end{array}$ & $\begin{array}{l}\text { pengetahuan } \\
\text { awalpeserta didik. }\end{array}$ & $\begin{array}{l}\text { Engagement identik dengan } \\
\text { Predict pada POEW }\end{array}$ \\
\hline 2. & $\begin{array}{l}\text { (Observation) } \\
\text { Melakukan } \\
\text { penelitian, } \\
\text { pengamatan }\end{array}$ & $\begin{array}{l}\text { (Exploration) menguji } \\
\text { prediksi ,melakukan dan } \\
\text { mencatat rasil } \\
\text { pengamatan. }\end{array}$ & $\begin{array}{l}\text { (Observation) Melakukan } \\
\text { observasi/pengamatan Tahap } \\
\text { Exploration identik dengan } \\
\text { tahap observation pada } \\
\text { POEW. }\end{array}$ \\
\hline 3. & $\begin{array}{l}\text { (Explanation) } \\
\text { Yaitu memberi } \\
\text { penjelasan }\end{array}$ & $\begin{array}{l}\text { (Explation) } \\
\text { menjelaskan konsep } \\
\text { dengan kalimat mereka } \\
\text { sendiri }\end{array}$ & $\begin{array}{l}\text { (Explation) Menjelaskan Pada } \\
\text { tahap explanation identik } \\
\text { dengan explation pada } \\
\text { pendekatan konstruktivistik }\end{array}$ \\
\hline 4. & $\begin{array}{l}\text { (Write) } \\
\text { Membuat } \\
\text { kesimpulan }\end{array}$ & $\begin{array}{lr}\text { (Elaboration) Aplikasi } \\
\text { konsep dalam } \\
\text { kehidupan sehari-hari }\end{array}$ & $\begin{array}{lr}\text { (Elaboration) } & \text { Aplikasi } \\
\text { konsep dalam } & \text { kehidupan } \\
\text { sehari-hari } & \text { merupakan } \\
\text { pengembangan } & \text { dari } \\
\text { pendekatan Konstruktivistik }\end{array}$ \\
\hline 5. & & $\begin{array}{l}\text { (Evaluation) Evaluasi } \\
\text { terhadap pengetahuan, } \\
\text { keterampilan dan } \\
\text { perubahan proses } \\
\text { berfikir peserta didik }\end{array}$ & $\begin{array}{l}\text { (Write) Menuliskan hasil } \\
\text { diskusi sebagai kesimpulan. } \\
\text { Merupakan pengembangan } \\
\text { dari model POEW }\end{array}$ \\
\hline 6. & & & $\begin{array}{l}\text { (Evaluation) Evaluasi } \\
\text { terhadap efektifitas fase-fase } \\
\text { sebelumnya. Merupakan } \\
\text { pengembangan dari } \\
\text { pendekatan Konstruktivistik }\end{array}$ \\
\hline
\end{tabular}

Tabel 2. Kegiatan pembelajaran Model Pembelajaran Model $\mathrm{POE}_{2} \mathrm{WE}$

\begin{tabular}{|c|c|c|}
\hline Fase-fase & Kegiatan Guru & Kegiatan Peserta Didik \\
\hline Prediction & $\begin{array}{ll}\text { - } & \text { Menyampaikan tujuan } \\
& \text { pembelajaran. } \\
\text { - } & \text { Mengajukan pertanyaan } \\
& \text { kepada siswa } \\
\text { - } & \text { Menginventarisir prediksi } \\
& \text { dan alasan yang di } \\
\text { kemukakan peserta didik. }\end{array}$ & $\begin{array}{ll}\text { - } & \text { Memperhatikan } \\
\text { penjelasan dari guru. } \\
\text { - } \\
\text { Memprediksi jawaban } \\
\text { pertanyaan dari guru } \\
\text { - } \begin{array}{l}\text { Mendiskusikan hasil } \\
\text { prediksinya }\end{array}\end{array}$ \\
\hline Observation & $\begin{array}{ll}\text { - } & \text { Mendorong peserta didik } \\
\text { untuk bekerja secara } \\
\text { kelompok } \\
\text { - } \begin{array}{l}\text { Membagikan LKS } \\
\text { - }\end{array} \\
\text { Mengawasi kegiatan } \\
\text { percobaan yang dilakukan } \\
\text { oleh peserta didik }\end{array}$ & $\begin{array}{ll}\text { - } & \text { Membentuk kelompok } \\
\text { - } & \text { Melakukan percobaan } \\
\text { - } & \text { Mengumpulkan data } \\
& \text { hasil percobaan } \\
\text { - } & \begin{array}{l}\text { Melakukan diskusi } \\
\text { kelompok } \\
\text { - } \\
\text { Menyimpulkan hasil } \\
\text { percobaan }\end{array}\end{array}$ \\
\hline Explanation & 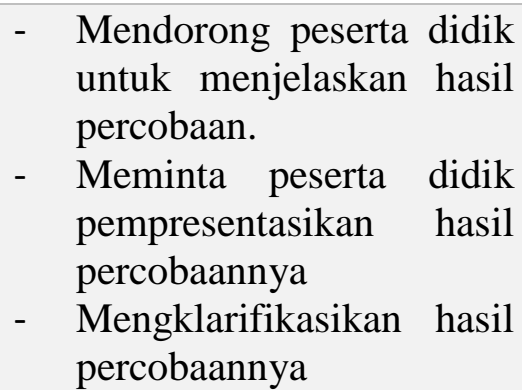 & 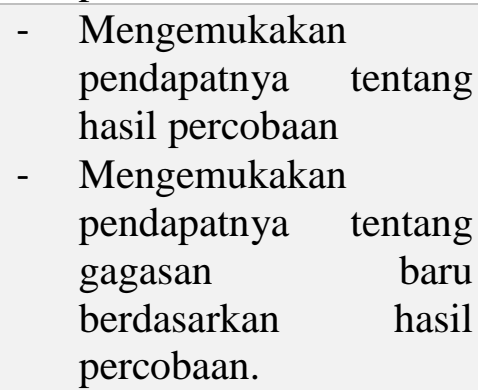 \\
\hline
\end{tabular}




\begin{tabular}{|c|c|c|}
\hline & $\begin{array}{ll}\text { - } & \text { Menjelaskan } \\
\text { konsep/definisi baru }\end{array}$ & $\begin{array}{ll}\text { - } & \text { Menanggapi presentasi } \\
\text { dari kelompok lain. } \\
\text { - } \\
\text { Konsep baru dari guru } \\
\text { dapat di terima }\end{array}$ \\
\hline Elaboration & 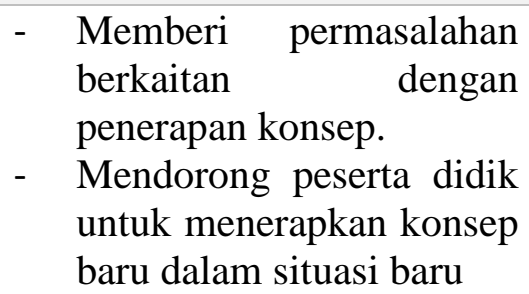 & $\begin{array}{l}\text { - Menerapkan konsep } \\
\text { baru dalam situasi baru } \\
\text { atau kehidupan sehari- } \\
\text { hari. }\end{array}$ \\
\hline Write & $\begin{array}{l}\text { - Memberi kesempatan } \\
\text { kepada peserta didik untuk } \\
\text { mencatat hasil diskusi } \\
\text { serta kesimpulan. }\end{array}$ & $\begin{array}{lr}\text { - } & \text { Mencatat } \\
\text { penjelasan } & \text { danil } \\
\text { kesimpulan dari guru } & \text { gun diskusi kelompok }\end{array}$ \\
\hline Evaluation & 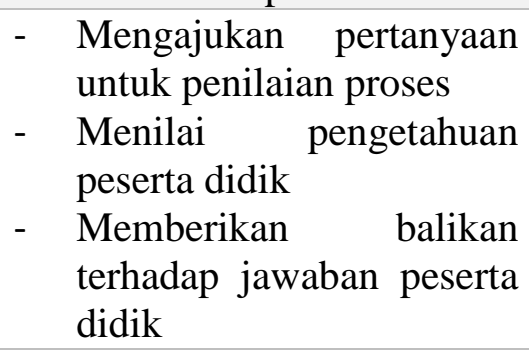 & $\begin{array}{l}\text { - Menjawab pertanyaan } \\
\text { berdasarkan data } \\
\text { - Mendemonstrasikan } \\
\text { kemampuan dalam } \\
\text { penguasaan konsep }\end{array}$ \\
\hline
\end{tabular}

Sumber: Nana, N., \& Surahman, E. Pengembangan Inovasi Pembelajaran Digital Menggunakan Model Blended POE2WE di Era Revolusi Industri 4.0. In Prosiding SNFA (Seminar Nasional Fisika dan Aplikasinya) (Vol. 4, pp. 82-90).

\section{B. Media Powtoon}

Media adalah sebagai alat grafis dan foto grafis untuk menangkap, memproses atau menyusun kembali informasi visual atau verbal (Sukirman, 2015:43). Pengembangan materi ajar dengan media membuat pembelajaran menjadi lebih terarah dan lebih menarik. Sehingga siswa merasa mempunyai rasa ingin tahu yang besar dan fokus memperhatikan pembelajaran.

Menurut Kustandi (2011:9) media pembelajaran adalah alat yang dapat membantu proses belajar mengajar dan berfungsi untuk memperjelas makna pesan yang disampaikan, sehingga dapat mencapai tujuan pembelajaran dengan lebih baik dan sempurna. Media pembelajaran dapat dikelompokkan menjadi empat kelompok yaitu media hasil teknologi cetak, media hasil teknologi audio visual, media hasil teknologi berbasis komputer, serta media hasil gabungan teknologi cetak dan computer.

Video pembelajaran audio visual yang digunakan dalam penelitian ini menggunakan aplikasi video PowToon. Media pembelajaran dengan video PowToon merupakan suatu proses pembelajaran yang dikemas ke dalam media inovatif dan menghibur. Pada saat pembelajaran berlangsung terlebih dahulu guru menyampaikan sedikit ulasan tentang materi yang akan diberikan, kemudian dilanjutkan dengan menayangkan video PowToon kepada siswa.

PowToon merupakan layanan online untuk membuat sebuah paparan yang memiliki fitur animasi sangat menarik. Fitur animasi tersebut dapat berupa animasi tulisan tangan, animasi kartun, dan efek transisi yang lebih hidup serta pengaturan time 
line yang sangat mudah. Hampir semua fitur dapat diakses dalam satu layar dan mudah digunakan dalam proses pembuatan sebuah paparan.

Sebagaimana Bahtraedu dalam postingannya memberikan beberapa kelebihan dari penggunaan media powtoon dalam pembelajaran, kelebihan tersebut antara lain:

1. Interaktif

2. Mencakup segala aspek indera

3. Penggunaannya praktis

4. Kolaboratif

5. Dapat digunakan dalam kelompok besar

6. Lebih variatif

7. Dapat memberikan feedback

8. Memotivasi.(http://bahtra12.blogspot.co.id/2015/04/mediapembelajaranpowtoon.html)

Berdasarkan kelebihan media powtoon di atas, salah satu kelebihan media powtoon adalah dapat memotivasi. Dalam kegiatan belajar mengajar peranan motivasi sangat diperlukan, sehingga penting bagi seorang guru untuk terus memotivasi peserta didiknya. Motivasi mempunyai fungsi sebagai energi penggerak terhadap tingkah laku, menentukan arah perbuatan, dan menentukan intensitas suatu perbuatan. Menurut Nyayu Khodijah (2014:150) "Motivasi adalah suatu dorongan yang mengubah energi dalam diri seseorang ke dalam bentuk aktivitas nyata untuk mencapai tujuan tertentu". Motivasi dapat juga dikatakan serangkaian usaha untuk menyediakan kondisi-kondisi tertentu, sehingga seseorang mau dan ingin melakukan sesuatu, dan bila ia tidak suka, maka akan berusaha untuk meniadakan atau mengelakkan perasaan tidak suka itu (Sardiman, 2012: 75).

Disamping itu, powtoon juga memiliki kelemahan. Adapun kelemahan aplikasi powtoon adalah sebagai berikut.

1. Presentasi menggunakan powtoon itu kurang efektif. Terutama di jenjang perguruan tinggi. Karena durasi yang digunakan itu terlalu singkat sehingga sangat sulit bagi peserta untuk memahami materi yang akan disampaikan.

2. Proses pembuatannya harus terhubung ke internet dan memerlukan waktu yang lama, minimal lima jam.

3. Tidak bisa diberi musik latar belakang dari aplikasinya secara langsung. Jika dilakukan maka akan blank. Dan harus mengulang dari awal lagi.

4. Perlu disesuaikan antara perkakasan dan keperluan perisian

5. Memerlukan kemahiran asas untuk menggunakannya.

\section{Pengaruh Penggunaan Model Pembelajaran POE 2 WE Berbantuan Media Video} Powtoon Pada Materi Dinamika Rotasi

Model pembelajaran POE2WE dapat menjadikan peserta didik sebagai subjek di dalam pembelajaran. peserta didik secara aktif menemukan suatu konsep melalui pengamatan. (Nana, E Surahman, 2019). Media video yang dilakukan dapat membantu peserta didik memahami materi dinamika rotasi dengan baik. Media video sangat efektif digunakan saat pembelajaran karena bisa membantu materi dinamika rotasi menjadi lebih menarik dan tidak membosankan. Oleh karena itu penulis mencoba menggunakan media Powtoon untuk pemahaman pada konsep dinamika rotasi. 
Media Pembelajaran Powtoon berfungsi Memperjelas penyajian pesan agar tidak terlalu bersifat verbalistis (dalam bentuk kata-kata tertulis atau lisan belaka); Mengatasi keterbatasan ruang, waktu dan daya indera, seperti misalnya: Objek yang terlalu besar, bisa digantikan dengan realita, gambar, film bingkai, film, atau model; Objek yang kecil-dibantu dengan proyektor mikro, film bingkai, film, atau gambar; Gerak yang terlalu lambat atau terlalu cepat, dapat dibantu dengan timelapse atau highspeed photography; Kejadian atau peristiwa yang terjadi di masa lalu bisa ditampilkan lagi lewat rekaman film, video, film bingkai, foto maupun secara verbal; Objek yang terlalu kompleks (misalnya mesin-mesin) dapat disajikan dengan model, diagram, dan lain-lain, dan Konsep yang terlalu luas (gunung berapi, gempa bumi, iklim, dan lainlain) dapat di visualkan dalam bentuk film, film bingkai, gambar, dan lain-lain.

Penggunaan media pendidikan secara tepat dan bervariasi dapat mengatasi sikap pasif anak menimbulkan kegairahan belajar, memungkinkan interaksi yang lebih langsung antara anak didik dengan lingkungan dan kenyataan, memungkinkan anak didik belajar sendiri-sendiri menurut kemampuan dan minatnya, memberikan perangsang yang sama, mempersamakan pengalaman, dan menimbulkan persepsi yang sama. Dengan aplikasi PowToon guru dapat menampilkann konsep dari Dinamika rotasi dengan tampilan yang lebih menarik dengan fitur-fitur yang ditawarkan sehingga pembelajaran konsep yang cenderung membosankan dan membingungkan menjadi lebih mudah. Guru pun hanya perlu memberikan tambahan penjelasan apa yang belum dijelaskan dalam aplikasi tersebut.

\section{KESIMPULAN}

Pengembangan inovasi pembelajaran blended learning dalam pembelajaran Fisika dengan model POE2WE dikategorikan sebagai hal baru. Pengembangan model ini lebih menyentuh ranah media Video pembelajaran sebagai jawaban atas tuntutan revolusi industry 4.0. Akan tetapi, inovasi pembelajaran ini masih dalam tahap pengembangan dan masih perlu perbaikan atau peningkatan dari berbagai aspek.

\section{UCAPAN TERIMA KASIH}

Alhamdulillah puji syukur kepada Allah swt, karena kehendak dan ridhaNya peneliti dapat menyelesaikan jurnal ini. Peneliti sadari jurnal ini tidak akan selesai tanpa doa, dukungan dan dorongan dari berbagai pihak. Adapun dalam kesempatan ini peneliti ingin mengucapkan banyak terima kasih kepada:

1. Dr. Nana M.Pd. selaku dosen pengampu mata kuliah Fisika Sekolah 2

2. Semua pihak yang tidak dapat disebutkan satu persatu, terima kasih atas segalanya.

\section{REFERENSI}

Bahtraedu. (2015). Media Pembelajaran Powtoon. (Online). http://bahtra12.blogspot.co.id/2015/04/media-pembelajaran-powtoon.html.

Diakses tanggal 29 Februari 2020.

Renaldy Suteja, Jimmy Anthony Sarapung \& Wilfridus Bambang Triadi Hanjaya. (2008). Memasuki Dunia eLearning. Bandung: Informatika.

Kustandi, Cecep \& Bambang Sutjipto. 2011. Media Pembelajaran. Bogor: Ghalia Indonesia 
Mersand, Shannon (2014). Product Review: PowToon. (Online). http://www.techlearning.com/news/0002/product-review-powtoon/63310. Diakses 29 Februari 2020.

Nana, D. R., \& Muhammad, A. Sajidan 2016 The Effectiveness of Scientific Approach Through Predict, Observe, Explain, Elaborate, Write and Evaluation (POE2WE) Model on the Topic of Kinetics (Rectilinear Motion) at Senior High School. The Social Sciences, 11(6), 1028-1034.

Nana, N., \& Surahman, E. Pengembangan Inovasi Pembelajaran Digital Menggunakan Model Blended POE2WE di Era Revolusi Industri 4.0. In Prosiding SNFA (Seminar Nasional Fisika dan Aplikasinya) (Vol. 4, pp. 82-90).

Nana, S., Akhyar, M., \& Rochsantiningsih, D. (2014). The Development Of Predict, Observe, Explain, Elaborate, Write, And Evaluate (POE2WE) Learning Model In Physics Learning At Senior Secondary School. Development, 5(19).

Khodijah, Nyayu (2014) Psikologi Pendidikan. Jakarta: PT Raja Grafindo Persada.

A.M.Sardiman (2012). Interaksi \& Motivasi belajar Mengajar. Jakarta: PT Raja Grafindo Persada.

Syaiful Bahri Djamarah dan Aswan Zain. (2013). Strategi Belajar Mengajar. Jakarta: Rineka Cipta.

Yamin, M., \& Ansari, B. I. (2012). Taktik mengembangkan kemampuan individual siswa. Jakarta: Gaung Persada Press. 